\title{
Toxoplasmosis in Pregnant Women and HIV/AIDS Patients in Ethiopia: A Systematic Review and Meta-Analysis
}

\author{
Daniel Getacher Feleke $\mathbb{D}^{\mathrm{D}},{ }^{1}$ Angesom Gebreweld ${ }^{(D)},{ }^{1}$ and Gashaw Zewde ${ }^{2}$ \\ ${ }^{1}$ Department of Medical Laboratory Science, College of Medicine and Health Sciences, Wollo University, Dessie, Ethiopia \\ ${ }^{2}$ Department of Medical Laboratory Science, Ataye District Primary Hospital, Ataye, Ethiopia
}

Correspondence should be addressed to Daniel Getacher Feleke; danibest2002@gmail.com

Received 14 November 2018; Revised 12 April 2019; Accepted 28 July 2019; Published 17 September 2019

Academic Editor: Bernard Marchand

Copyright (C) 2019 Daniel Getacher Feleke et al. This is an open access article distributed under the Creative Commons Attribution License, which permits unrestricted use, distribution, and reproduction in any medium, provided the original work is properly cited.

\begin{abstract}
Background. Although Toxoplasma gondii infection in immune-competent individuals is usually asymptomatic or causes a mild flulike illness, it may become severe and can occasionally be fatal in immune-compromised people, such as AIDS patients or pregnant women. Method. Electronic English databases (Pubmed, Google Scholar, Science Direct, and Scopus), parasitology congresses, and theses of Ethiopian medical universities, were systematically searched (published or unpublished data). Full-length articles and abstracts were collected using keywords such as Toxoplasma gondii, Toxoplasmosis, pregnant women, HIV/AIDS, and Ethiopia. Results. Analysis of seroprevalence estimates was pooled using a random effects meta-analysis. Seventeen studies were included in the present systematic review and meta-analysis. One of these studies reported seroprevalence of T. gondii in HIV/AIDS patients and pregnant women. In this review, a total of 4,030 individuals were included and analyzed. The pooled prevalence of T. gondii in this review was $81.00 \%(95 \% \mathrm{CI}=69.10-89.78)$. Sub-group analysis showed that 2,557 pregnant women were evaluated. In pregnant women, the pooled sero-prevalence was $71.2(95 \% \mathrm{CI}=[51.9 \%, 87.1 \%]$. In HIV/AIDS patients, 1,473 individuals were evaluated and the pooled seroprevalence was 88.45 (95\% CI $=80.87 \%-94.31 \%)$. Conclusion. This systematic review and meta-analysis identified a high seroprevalence of Toxoplasma infection of $81 \%$ among immunocompromised patients. Scaling up prevention and control methods mainly strengthening educational efforts are necessary to avoid reactivation and to stop the spread of $T$. gondii infection.
\end{abstract}

\section{Introduction}

Toxoplasma gondii is one of the most prevalent obligate intracellular protozoan parasites of man and livestock [1-5]. Feline species are definitive hosts for Toxoplasma gondii and a wide range of animals serve as intermediate hosts. Globally, it is estimated that about one-third of the population is infected with T. gondii [3]. Although T. gondii infection in immune-competent individuals is usually asymptomatic or causes a mild flu-like illness [4], it may become severe and can occasionally be fatal in immune-compromised people, such as AIDS patients or pregnant women $[2,6]$. Toxoplasma gondii infection in AIDS patients and pregnant women causes severe encephalitis, and neurologic diseases, and can affect the heart, liver, inner ears, and eyes (chorioretinitis) [2]. Infection with T. gondii during pregnancy can result in spontaneous abortion, still-birth, fetal death, neonatal death, or various congenital defects, such as hydrocephalus, central nervous system abnormalities, and chorioretinitis [7]. HIV infected individuals are at risk of acute toxoplasmosis due to reactivation of T. gondii. It also causes cervical lymphadenopathy or ocular disease in HIV infected immune competent individuals.

Humans get infections with $T$. gondii after ingesting raw or undercooked meat, by ingesting cat-shed oocysts via contaminated soil, food or water; or trans-placental transmission $[3-5,7]$.

Serological methods used for T. gondii diagnosis such as enzyme-linked immunesorbent assay (ELISA) and indirect immunofluorescence assay (IFA) are considered as gold standard for the detection of Toxoplasma-specific antibodies (IgG or IgM) [4].

In Ethiopia, human toxoplasmosis infection is a neglected disease [7]. The prevalence of T. gondii infection in Ethiopia has been reported in some populations; mainly in HIV 


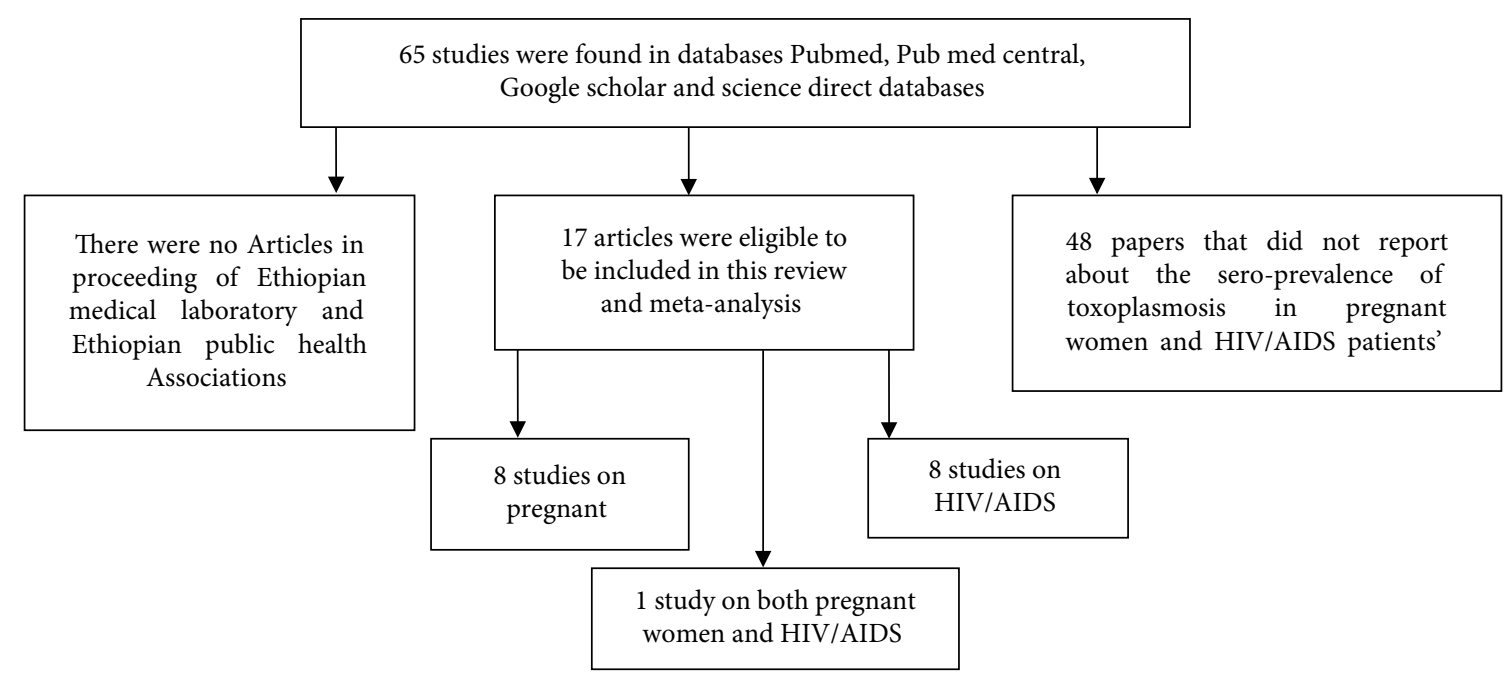

FIgURE 1: Briefly shows the search process in this review article.

infected individuals, pregnant women, child bearing age women, and in general population [4].

For appropriate diagnosis, treatment, and control of $T$. gondii infections, information about the seroprevalence of toxoplasmosis in different special populations is very important. So, this systematic review of the literature aimed to evaluate the sero-prevalence of T. gondii among pregnant women and HIV/AIDS patients in Ethiopia.

\section{Methods}

2.1. Literature Search and Data Extraction. Relevant literatures were searched on Pubmed, Pubmed central, Google scholar, science direct databases, Scopus, theses of Ethiopian medical universities, and Ethiopian journals such as Ethiopia journal of health development and proceedings of professional associations from May, 2018 to June, 2018. Full-length articles and abstracts were collected using keywords such as Toxoplasma gondii, Toxoplasmosis, pregnant women, HIV/ AIDS, and Ethiopia. These key words were also used in combination using boolean operators. Overlapped articles found in more than one databases were excluded. Annual research conferences and preceding of Ethiopian medical laboratory association (EMLA), and Ethiopian public health laboratory associations' (EPHLAs) records were reviewed to identify relevant unpublished articles.

The reference lists of published studies included in this meta-analysis were searched for additional articles. Two authors independently reviewed all collected studies for eligibility and they extracted the required information based on the objective this meta-analysis.

2.2. Data Collection. Pre-designed data extraction form was developed by authors based on the objective of this review. Studies conducted in Ethiopia to estimate the sero-prevalence of $T$. gondii infection in pregnant women and HIV/AIDS patients were included. All collected studies were assessed by two authors for eligibility to be included in this review. In case of disagreement on the eligibility of identified studies, authors held discussion to resolve the issue by considering the quality of identified study and the aim of the present review. Studies performed in study groups other than pregnant women, and HIV/AIDS and those studies that did not use random sampling methods as a sampling technique were excluded (Figure 1). Information about year of publication, first author, study area, study design, total sample size, number of seropositive individuals, and laboratory methods used for T. gondii diagnoses was carefully investigated.

2.3. Statistical Analysis. Point estimates and 95\% confidence intervals of seroprevalence of all included studies were calculated. An overall seroprevalence and group-specific seroprevalences were calculated among HIV/AIDS patients and pregnant women. Heterogeneity among studies was visualized using a forest plot chart. The $I^{2}$ and Cochran's Q tests were used to quantify the variations between studies. The heterogeneity was considered not significant when $P>0.1$ and $I^{2}<50 \%$. Due to the heterogeneity of studies included in this metaanalysis, random effect model was used by considering the included studies used random samples from a population. This meta-analysis was performed using the trial version of StatsDirect statistical software (https://statsdirect.com).

\section{Results}

Out of 65 studies from literature searches using key words, 17 studies were eligible and included in the present systematic review and meta-analysis. Eight studies described the sero-prevalence of T. gondii in pregnant women, whereas 8 studies reported $T$. gondii infection in HIV/AIDS patients. There was also one study which reported seroprevalence of $T$. gondii in HIV/AIDS patients and pregnant women. This study was considered in both pregnant women and HIV/AIDS patient groups during analysis. The study designs of all eligible and included studies were cross-sectional. In this review, Enzyme-linked immunosorbent assay (ELISA) and latex agglutination slide tests were the commonly used methods for 
TABLE 1: The baseline characteristics of the studies included in this literature search.

\begin{tabular}{|c|c|c|c|c|c|c|c|c|c|}
\hline Author & $\begin{array}{c}\text { Publication } \\
\text { Year }\end{array}$ & Study area & Study group & $\begin{array}{l}\text { No of } \\
\text { cases }\end{array}$ & $\begin{array}{c}\text { Total } \\
\text { sample size }\end{array}$ & $\begin{array}{l}\text { Sero-preva- } \\
\text { lence }\end{array}$ & $\begin{array}{l}\text { Age } \\
\text { range }\end{array}$ & $\begin{array}{l}\text { Serologic } \\
\text { test }\end{array}$ & Ref \\
\hline Shimelis T. & 2009 & Addis Ababa & $\begin{array}{l}\text { HIV/AIDS } \\
\text { patients }\end{array}$ & 154 & 165 & $93.3 \%$ & $20-66$ & ELISA & {$[8]$} \\
\hline Zemene E. & 2012 & Jimma town & $\begin{array}{l}\text { Pregnant } \\
\text { women }\end{array}$ & 168 & 201 & $83.6 \%$ & $17-35$ & ELISA & {$[3]$} \\
\hline Walle F. & 2013 & Bahir Dar & $\begin{array}{l}\text { HIV/AIDS } \\
\text { patients }\end{array}$ & 101 & 103 & $87.4 \%$ & NA & ELISA & [9] \\
\hline Alem H. & 2013 & $\begin{array}{c}\text { Addis Ababa } \\
\text { (Tikur Anbesa } \\
\text { Hospital) }\end{array}$ & $\begin{array}{l}\text { HIV/AIDS } \\
\text { patients }\end{array}$ & 141 & 150 & $94.0 \%$ & NA & ELISA & [10] \\
\hline Endris M. & 2013 & $\begin{array}{c}\text { University of } \\
\text { Gondar Hospital }\end{array}$ & $\begin{array}{l}\text { HIV/AIDS } \\
\text { patients }\end{array}$ & 130 & 170 & $76.5 \%$ & NA & LAT & {$[6]$} \\
\hline Hailu A. & 2014 & $\begin{array}{c}\text { Ethiopia selected } \\
\text { areas }\end{array}$ & $\begin{array}{l}\text { HIV/AIDS } \\
\text { patients }\end{array}$ & 178 & 190 & $93.6 \%$ & NA & ELISA & [11] \\
\hline Yohanes T. & 2014 & $\begin{array}{c}\text { Arba Minch } \\
\text { Hospital }\end{array}$ & $\begin{array}{l}\text { HIV/AIDS } \\
\text { patients }\end{array}$ & 150 & 170 & $88.2 \%$ & NA & ELISA & [12] \\
\hline Hailu A. & 2014 & $\begin{array}{c}\text { Ethiopia selected } \\
\text { areas }\end{array}$ & $\begin{array}{l}\text { Pregnant } \\
\text { women }\end{array}$ & 256 & 293 & $87.3 \%$ & NA & ELISA & [11] \\
\hline Endris $M$. & 2014 & $\begin{array}{c}\text { University of } \\
\text { Gondar Hospital }\end{array}$ & $\begin{array}{l}\text { Pregnant } \\
\text { women }\end{array}$ & 341 & 385 & $88.6 \%$ & NA & LAT & {$[6]$} \\
\hline Gelaye W. & 2015 & Addis Ababa & $\begin{array}{l}\text { Pregnant } \\
\text { women }\end{array}$ & 246 & 288 & $85.4 \%$ & $18-42$ & LAT & {$[4]$} \\
\hline Awoke K. & 2015 & $\begin{array}{l}\text { Felegehiwot Hos- } \\
\text { pital, Bahir dar }\end{array}$ & $\begin{array}{l}\text { Pregnant } \\
\text { women }\end{array}$ & 71 & 384 & $18.5 \%$ & NA & LAT & {$[5]$} \\
\hline Agmas B. & 2015 & $\begin{array}{c}\text { Debre Tabor } \\
\text { Hospital }\end{array}$ & $\begin{array}{l}\text { Pregnant } \\
\text { women }\end{array}$ & 180 & 263 & $68.4 \%$ & $18-44$ & LAT & {$[1]$} \\
\hline Mohammed K. & 2015 & $\begin{array}{l}\text { Mettu Karl Hos- } \\
\text { pital }\end{array}$ & $\begin{array}{l}\text { HIV/AIDS } \\
\text { patients }\end{array}$ & 72 & 120 & $60.0 \%$ & NA & LAT & [13] \\
\hline Abamecha F. & 2016 & $\begin{array}{c}\text { Mizan Aman } \\
\text { Hospital }\end{array}$ & $\begin{array}{l}\text { Pregnant } \\
\text { women }\end{array}$ & 198 & 232 & $85.3 \%$ & NA & ELISA & [7] \\
\hline Tegegne D. & 2016 & Agaro town & $\begin{array}{l}\text { HIV/AIDS } \\
\text { patients }\end{array}$ & 109 & 135 & $80.7 \%$ & NA & LAT & {$[14]$} \\
\hline Negero J. & 2017 & Bonga Hospital & $\begin{array}{l}\text { Pregnant } \\
\text { women }\end{array}$ & 159 & 210 & $75.7 \%$ & $15-44$ & LAT & [15] \\
\hline Negussie A. & 2017 & Jigjiga Hospital & $\begin{array}{l}\text { Pregnant } \\
\text { women }\end{array}$ & 105 & 301 & $34.9 \%$ & NA & LAT & {$[2]$} \\
\hline Jejaw A. & 2017 & $\begin{array}{c}\text { Mizan Aman } \\
\text { Hospital }\end{array}$ & $\begin{array}{l}\text { HIV/AIDS } \\
\text { patients }\end{array}$ & 261 & 270 & $96.7 \%$ & $18-49$ & ELISA & [16] \\
\hline
\end{tabular}

NA: not applicable.

the detection of T. gondii antibodies. The higher seroprevalence of T. gondii (96.7\% and 93.6\%) was reported in HIV/AIDS patients from Mizan Aman Hospital and selected areas of Ethiopia, respectively. On the other hand the lower seroprevalence (18.5\% and $34.9 \%$ ) reported in this study was in pregnant women from Felege Hiwot Hospital from Jigjiga Hospital (Tables 1, 2 and 3).

Detection of T. gondii IgG and IgM is one of the commonest serologic diagnoses. IgG detection indicates either past or present infection while the detection of IgM showed early infection of T. gondii. Based on IgG assessment, most of the current reviewed studies reported above 95\% T. gondii IgG sero-prevalence. In general, the sero-prevalence of IgG is higher than IgM in pregnant women and HIV/AIDS patients (Tables 1 and 2).
In general, in this review a total of 4,030 individuals were included and analyzed. The pooled prevalence of toxoplasmosis in this review was $81.00 \%(95 \% \mathrm{CI}=69.10-89.78)$. The $Q$ statistic and $\mathrm{I}_{2}$ (inconsistency) were Cochran $\mathrm{Q}=1,233.145293$ $(\mathrm{df}=17, P<0.0001)$ and $\mathrm{I}_{2}$ (inconsistency) $=98.6 \% \quad(95 \%$ $\mathrm{CI}=98.5 \%-98.8 \%$ ) (Figure 2). In this meta-analysis and systematic review, time interval sub-group analysis was performed to observe $T$. gondii sero-prevalence change from old studies to recent studies. Included studies from 2009 to 2017 were grouped in five years' interval. The pooled sero-prevalence of T. gondii from 2009 to 2013 was $90 \%$ (95\% CI=82\%-96\%) while it was $76 \%(95 \% \mathrm{CI}=61 \%-89 \%)$ in recent studies $(2014-$ 2017). Majority of the studies were conducted in recent years (2014-2017). Sub group analysis showed the sero-prevalence of T. gondi is decreased in recent years. 
TABLE 2: Baseline characteristics of included studies (based on IgG assessment).

\begin{tabular}{|c|c|c|c|c|c|c|c|c|c|c|}
\hline Author & $\begin{array}{l}\text { Publica- } \\
\text { tion year }\end{array}$ & Study area & $\begin{array}{l}\text { Study } \\
\text { group }\end{array}$ & $\begin{array}{l}\text { No of } \\
\text { cases }\end{array}$ & $\begin{array}{c}\text { sample } \\
\text { size }\end{array}$ & IgG cases & $\begin{array}{c}\text { Sero-prev- } \\
\text { alence }\end{array}$ & Age range & $\begin{array}{c}\text { Serologic } \\
\text { test }\end{array}$ & Ref \\
\hline Zemene E. & 2012 & Jimma town & $\begin{array}{c}\text { Pregnant } \\
\text { women }\end{array}$ & 168 & 201 & 163 & $97.0 \%$ & $17-35$ & ELISA & [3] \\
\hline Walle F. & 2013 & Bahir Dar & $\begin{array}{c}\text { HIV/ } \\
\text { AIDS } \\
\text { patients }\end{array}$ & 101 & 103 & 90 & $89.1 \%$ & NA & ELISA & [9] \\
\hline Alem H. & 2013 & $\begin{array}{c}\text { Addis } \\
\text { Ababa Tikur } \\
\text { Anbesa } \\
\text { Hospital }\end{array}$ & $\begin{array}{c}\text { HIV/ } \\
\text { AIDS } \\
\text { patients }\end{array}$ & 141 & 150 & 141 & $100.0 \%$ & NA & ELISA & {$[10]$} \\
\hline Hailu A. & 2014 & $\begin{array}{l}\text { Ethiopia } \\
\text { selected } \\
\text { areas }\end{array}$ & $\begin{array}{c}\text { Pregnant } \\
\text { women }\end{array}$ & 256 & 293 & 247 & $96.5 \%$ & NA & ELISA & {$[11]$} \\
\hline Endris $M$. & 2014 & $\begin{array}{c}\text { University } \\
\text { of Gondar } \\
\text { Hospital }\end{array}$ & $\begin{array}{c}\text { Pregnant } \\
\text { women }\end{array}$ & 341 & 385 & 341 & $100.0 \%$ & NA & LAT & [6] \\
\hline Hailu A. & 2014 & $\begin{array}{l}\text { Ethiopia } \\
\text { selected } \\
\text { areas }\end{array}$ & $\begin{array}{c}\text { HIV/ } \\
\text { AIDS } \\
\text { patients }\end{array}$ & 178 & 190 & 172 & $96.6 \%$ & NA & ELISA & [11] \\
\hline $\begin{array}{l}\text { Abamecha } \\
\text { F. }\end{array}$ & 2016 & $\begin{array}{c}\text { Mizan } \\
\text { Aman Hos- } \\
\text { pital }\end{array}$ & $\begin{array}{l}\text { Pregnant } \\
\text { women }\end{array}$ & 198 & 232 & 191 & $96.5 \%$ & NA & ELISA & [7] \\
\hline Jejaw A. & 2017 & $\begin{array}{c}\text { Mizan } \\
\text { Aman Hos- } \\
\text { pital }\end{array}$ & $\begin{array}{c}\text { HIV/ } \\
\text { AIDS } \\
\text { patients }\end{array}$ & 261 & 270 & 255 & $97.7 \%$ & $18-49$ & ELISA & [16] \\
\hline
\end{tabular}

NA: not applicable.

TABLE 3: Baseline characteristics of included studies (based on IgM assessment).

\begin{tabular}{|c|c|c|c|c|c|c|c|c|c|c|}
\hline Author & $\begin{array}{l}\text { Publica- } \\
\text { tion year }\end{array}$ & Study area & $\begin{array}{l}\text { Study } \\
\text { group }\end{array}$ & $\begin{array}{l}\text { No of } \\
\text { cases }\end{array}$ & $\begin{array}{c}\text { Sample } \\
\text { size }\end{array}$ & $\begin{array}{l}\text { IgM posi- } \\
\text { tive }\end{array}$ & $\begin{array}{l}\text { Sero-prev- } \\
\text { alence }\end{array}$ & Age range & $\begin{array}{l}\text { Serologic } \\
\text { test }\end{array}$ & Ref \\
\hline Zemene E. & 2012 & $\begin{array}{c}\text { Jimma } \\
\text { town }\end{array}$ & $\begin{array}{l}\text { Pregnant } \\
\text { women }\end{array}$ & 168 & 201 & 2 & 1.2 & $17-35$ & ELISA & [3] \\
\hline Walle $\mathrm{F}$. & 2013 & Bahir dar & $\begin{array}{l}\text { HIV/AIDS } \\
\text { patients }\end{array}$ & 101 & 103 & 11 & 10.89 & NA & ELISA & [9] \\
\hline Hailu A. & 2014 & $\begin{array}{c}\text { Ethiopia } \\
\text { selected } \\
\text { areas }\end{array}$ & $\begin{array}{l}\text { Pregnant } \\
\text { women }\end{array}$ & 256 & 293 & 9 & 3.52 & NA & ELISA & [11] \\
\hline Hailu A. & 2014 & $\begin{array}{c}\text { Ethiopia } \\
\text { selected } \\
\text { areas }\end{array}$ & $\begin{array}{l}\text { HIV/AIDS } \\
\text { patients }\end{array}$ & 178 & 190 & 6 & 3.37 & NA & ELISA & [11] \\
\hline Abamecha F. & 2016 & $\begin{array}{c}\text { Mizan } \\
\text { Aman } \\
\text { Hospital }\end{array}$ & $\begin{array}{l}\text { Pregnant } \\
\text { women }\end{array}$ & 198 & 232 & 7 & 3.54 & NA & ELISA & [7] \\
\hline Jejaw A. & 2017 & $\begin{array}{c}\text { Mizan } \\
\text { Aman } \\
\text { Hospital }\end{array}$ & $\begin{array}{c}\text { HIV/AIDS } \\
\text { patients }\end{array}$ & 261 & 270 & 6 & 2.3 & $18-49$ & ELISA & [16] \\
\hline
\end{tabular}

NA: not applicable.

Sub-group analysis showed that 2,557 pregnant women were included and evaluated. Random effect analysis was used due to the heterogeneity between studies. The $Q$ statistic and the pooled sero-prevalence were Cochran $\mathrm{Q}=845.808548$ $(\mathrm{df}=8, P<0.0001)$ and $71.2(95 \% \mathrm{CI}=[51.9 \%, 87.1 \%]$ respectively (Figure 3$). \mathrm{I}_{2}$ (inconsistency) $=99.1 \%(95 \% \mathrm{CI}=[98.9 \%$, 99.2\%] (Figure 3).
In HIV/AIDS patients, 1,473 individuals were included and evaluated. The $Q$ statistic and the pooled seroprevalence were Cochran $\mathrm{Q}=136.254836(\mathrm{df}=8, P<0.0001)$ and 88.45 $(95 \% \quad \mathrm{CI}=80.87 \%-94.31 \%) \quad$ respectively. $\mathrm{I}_{2}$ (inconsistency $)=94.1 \%(95 \% \mathrm{CI}=91.5 \%-95.7 \%)$ (Figure 4$)$.

Begg and Egger tests were used for evaluating publication bias. Significant publication bias was not revealed in studies 
Proportion meta-analysis plot [random effects]

Zemene E. 2012. Jimma town. LAT

Hailu A. 2014. Ethiopia selected areas. ELISA

Endris M. 2014. University of Gondar. ELISA

Agmas B. 2015. Debre Tabor. LAT

Gelaye W. 2015. Addis Ababa. LAT

Awoke K. 2015. Bahirdar. LAT

Abamecha F. 2016. Mizan Aman. LAT

Negussie A. 2017. Jigjiga. LAT

Negero J. 2017. Bonga Hospital. LAT

Shimelis T. 2009. Addis Ababa. ELISA

Alem H. 2013. Addis Ababa Tikur anbesa Hospital. E

Endris M. 2013. University of Gondar. LAT

Walle F. 2013.Bahirdar. ELISA

Yohanes T. 2014, Arbaminch Hospital. ELISA

Hailu A. 2014. Ethiopia selected areas. ELISA

Mohammed K. 2015. Mettu Karl Hospital. LAT

Tegegne D. 2016. Agaro town. LAT

Jejaw A. 2017. Mizan Aman Hospital. ELISA

Combined
$0.84(0.78,0.88)$

$0.87(0.83,0.91)$

$0.89(0.85,0.92)$

$0.68(0.62,0.74)$

$0.85(0.81,0.89)$

$0.18(0.15,0.23)$

$0.85(0.80,0.90)$

$0.35(0.30,0.41)$

$0.76(0.69,0.81)$

$0.93(0.88,0.97)$

$0.94(0.89,0.97)$

$0.76(0.69,0.83)$

$0.98(0.93,1.00)$

$0.88(0.82,0.93)$

$0.94(0.89,0.97)$

$0.60(0.51,0.69)$

$0.81(0.73,0.87)$

$0.97(0.94,0.98)$

$0.81(0.69,0.90)$

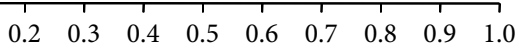

Proportion (95\% confidence interval)

FIGURE 2: Forest plot diagram of studies showing seropositivity to T. gondii in pregnant women and HIV/AIDS patients from Ethiopia.

included about pregnant women $(P$-value $>0.05)$. There was significant bias among studies included about HIV/AIDS patients $(P$-value $>0.05)$.

\section{Discussion}

Toxoplasma gondii infection is usually asymptomatic in immune-competent individuals or causes a mild illness [4]. However, it may become severe and can occasionally be fatal in immune-compromised people, such as HIV/AIDS patients or pregnant women $[2,6]$.

This is the first systematic review and meta-analysis of toxoplasmosis in pregnant women and HIV/AIDS patients in Ethiopia. Among 2,557 pregnant women in Ethiopia, the sero-prevalence of T. gondii was $71.1 \%$. Furthermore, the seroprevalence of $T$. gondii in 1,473 HIV/AIDS patients was $88.45 \%$. Immune compromised patients are at high risk of toxoplasmosis reactivation [17]. The finding of this meta-analysis showed that the seroprevalence of $T$. gondii in pregnant women and HIV/AIDS patients was higher than $70 \%$, and there is a risk of reactivation of T.gondii in this group of population. Toxoplasmosis is an opportunistic disease that can cause very severe illness and fatality in immune compromised individuals. Pregnant women and HIV/AIDS patients are immune deficient individuals. This immune inefficiency could be the main risk factor for the higher sero-prevalence of $T$. gondii.

Toxoplasmosis is mainly transmitted to human by ingestion of oocysts with contaminated food and drinks, by consumption raw or undercooked meat contain bradyzoites. It can also be transmitted during blood transfusion and organ transplantation.

Immunocompromised patients are highly vulnerable groups for toxoplasmosis infection due to debilitated immune system.

In Ethiopia, human toxoplasmosis infection is a neglected disease [7]. Some studies were conducted on the seroprevalence of toxoplasmosis. The study group of majority of the studies was on pregnant women, general population, and HIV/ 
Proportion meta-analysis plot [random effects]

Zemene E. 2012. Jimma town. LAT

Hailu A. 2014. Ethiopia selected areas. ELISA

Endris M. 2014. University of Gondar. ELISA

Agmas B. 2015. Debre Tabor. LAT

Gelaye W. 2015. Addis Ababa. LAT

Awoke K. 2015. Bahirdar. LAT

Abamecha F. 2016. Mizan Aman. LAT

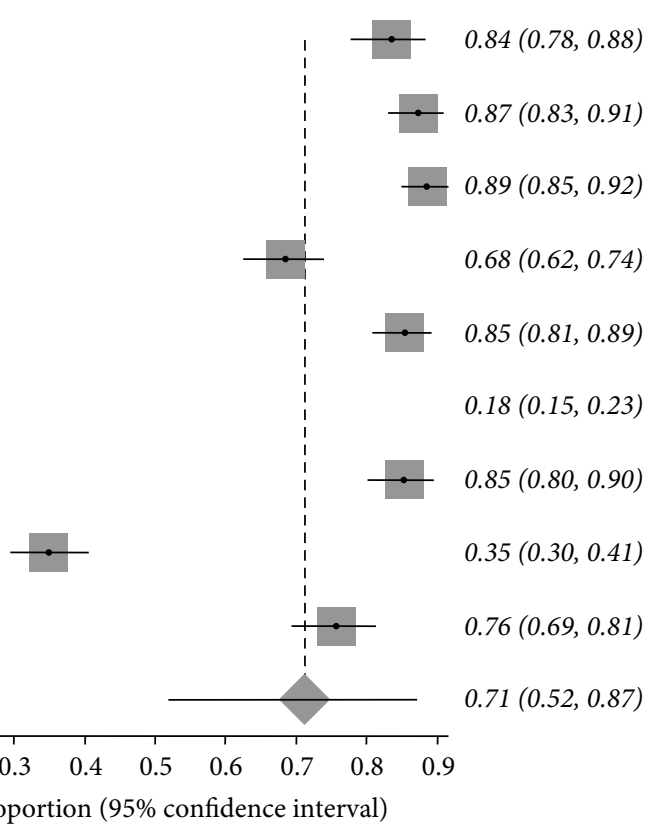

FIGURE 3: Forest plot diagram of studies showing seropositivity of T. gondii in pregnant women from Ethiopia.

Proportion meta-analysis plot [random effects]

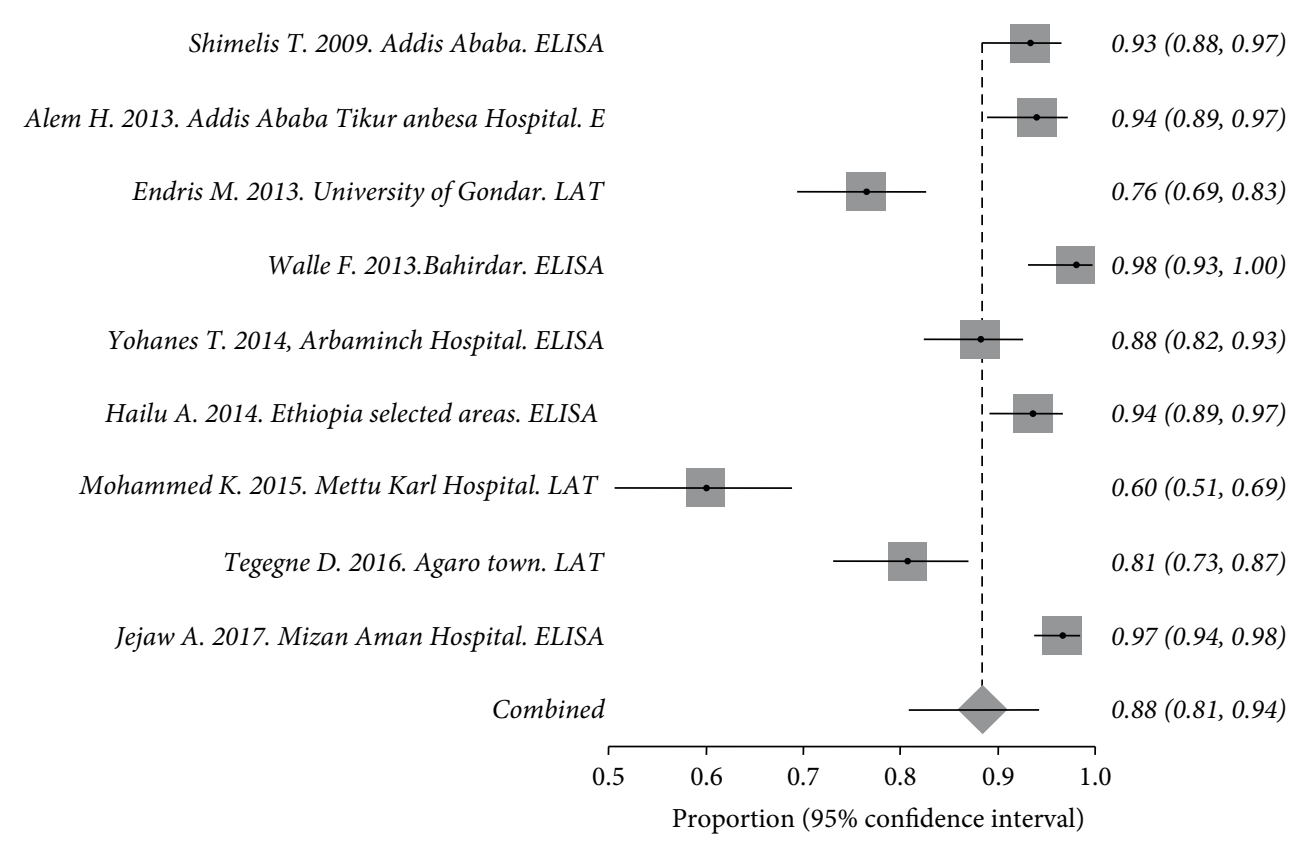

FIGURE 4: Forest plot diagram of studies showing seropositivity of T. gondii in HIV/AIDS patients from Ethiopia.

AIDS patients. Toxoplasmosis in this group of the population can have devastating consequences. For instance, congenitally transmitted toxoplasmosis in pregnant women can have serious disease in fetus including chorioretinitis and neurological complications. In HIV/AIDS patients beside the virus toxoplasmosis may play a role in immune suppression and fasten the onset of AIDS symptoms.
Serological tests are considered as the gold standard in the diagnosis of T. gondii infection. Due to some shortcomings in serologic tests and the variation of serologic methods used, the seroprevalence of $T$. gondii infection might be varied.

In Ethiopia, T. gondii seroprevalence studies in pregnant women and HIV/AIDS mainly used latex agglutination test 
and Enzyme linked immune sorbent assay (ELISA) methods for diagnosis. The highest prevalence of toxoplasmosis was observed in individuals diagnosed with ELISA. For instance, in HIV/AIDS patients, $96.70 \%$ sero-prevalence of T. gondii was observed using ELISA. The incidence and prevalence of T. gondii infection varies depending on geographic areas, weather conditions, and age groups in Ethiopia. In Ethiopia, a review studied on the sero-prevalence of $T$. gondii in general population revealed the overall pooled prevalence was $74.73 \%$ [18]. The seropositivity in pregnant women and HIV/AIDS patients in the present study was $71.1 \%$ and $88.45 \%$, respectively. The seroprevalence in HIV/AIDS patients was higher than reported from general population and pregnant women sero-prevelence in the present study.

\section{Conclusions}

As far as we know and our literature search, this is the first systematic review and meta-analysis that provides information about the seroprevalence of $T$. gondii in pregnant women and HIV/AIDS patients in Ethiopia. Our finding indicates that researchers must give attention to the seroprevalence of toxoplasmosis in immunocompromised patients especially in HIV/AIDS patients, and pregnant women. Scaling up prevention and control methods and mainly strengthening educational efforts are necessary to avoid reactivation and to stop the spread of T. gondii infection.

\section{Data Availability}

The authors confirm that all data underlying the findings are fully available without restriction. All relevant data are within the manuscript.

\section{Ethical Approval}

After discussing the aim and the information required for this systematic review and meta-analysis, a letter of approval was obtained from the Department of Medical Laboratory Sciences Research Committee, College of Medicine and Health Science, Wollo University.

\section{Conflicts of Interest}

The authors declare that they have no conflicts of interest.

\section{Authors' Contributions}

DG, GZ, and AG were involved in proposal writing; they designed the study and participated in all implementation stages of the project. DGF and GZ also analyzed the data and finalized the write up of the manuscript. DGF, GZ, and AG were responsible for critically revising the proposal and the manuscript. All authors reviewed and approved the final manuscript.

\section{Abbreviations}

HIV: Human immunodeficiency virus

AIDS: Acquired immunodeficent syndrome

ELISA: Enzyme linked immunosorbent assay

LAT: Latex agglutination test.

\section{Acknowledgments}

The authors acknowledge Wollo University Medical Laboratory Science department staff. The authors also thank all their colleagues for their cooperation in the accomplishment of this study.

\section{References}

[1] B. Agmas, R. Tesfaye, and D. N. Koye, "Seroprevalence of Toxoplasma gondii infection and associated risk factors among pregnant women in Debre Tabor, Northwest Ethiopia," BMC Research Notes, vol. 8, no. 1, Article ID 107, 2015.

[2] A. Negussie, E. Beyene, and S. Palani, "Toxoplasmosis and associated risk factors in antenatal clinic follow up Pregnant Women in Selected Health Institutes of Jigjiga, East Ethiopia," International Journal of Tropical Disease \& Health, vol. 21, no. 3, pp. 1-7, 2017.

[3] E. Zemene, D. Yewhalaw, S. Abera, T. Belay, A. Samuel, and A. Zeynudin, "Seroprevalence of Toxoplasma gondii and associated risk factors among pregnant women in Jimma town, Southwestern Ethiopia," BMC Infectious Diseases, vol. 12, no. 1, Article ID 337, 2012.

[4] W. Gelaye, T. Kebede, and A. Hailu, "High prevalence of antitoxoplasma antibodies and absence of Toxoplasma gondii infection risk factors among pregnant women attending routine antenatal care in two hospitals of Addis Ababa Ethiopia," International Journal of Infectious Diseases, vol. 34, pp. 41-45, 2015.

[5] K. Awoke, E. Nibret, and A. Munshea, "Sero-prevalence and associated risk factors of Toxoplasma gondii infection among pregnant women attending antenatal care at Felege Hiwot Referral Hospital, Northwest Ethiopia," Asian Pacific Journal of Tropical Medicine, vol. 8, no. 7, pp. 549-554, 2015.

[6] M. Endris, Y. Belyhun, F. Moges et al., "Seroprevalence and associated risk factors of Toxoplasma gondii in pregnant women attending in Northwest Ethiopia," Iranian Journal of Parasitology, vol. 9, no. 3, pp. 407-414, 2014.

[7] F. Abamecha and H. Awel, "Seroprevalence and risk factors of Toxoplasma gondii infection in pregnant women following antenatal care at Mizan Aman General Hospital, Bench Maji Zone (BMZ), Ethiopia," BMC Infectious Diseases, vol. 16, no. 1, Article ID 460, 2016.

[8] T. Shimelis, M. Tebeje, E. Tadesse, B. Tegbaru, and A. Terefe, "Sero-prevalence of latent Toxoplasma gondii infection among HIV-infected and HIV-uninfected people in Addis Ababa, Ethiopia: a comparative cross-sectional study," BMC Research Notes, vol. 2, no. 1, p. 213, 2009.

[9] F. Walle, N. Kebede, A. Tsegaye, and T. Kassa, "Seroprevalence and risk factors for Toxoplasmosis in HIV infected and noninfected individuals in Bahir Dar, Northwest Ethiopia," Parasites \& Vectors, vol. 6, no. 1, p. 15, 2013. 
[10] H. Aleme, G. Tilahun, D. Fekade, N. Berhe, and G. Medhin, "Sereoprevalence of immunoglobulin-G and of immunoglobulin-M anti-Toxoplasma gondii antibodies in human immunodeficiency virus infection/acquired immunodeficiency syndrome patients at Tikur Anbessa Specialized Hospital, Addis Ababa Ethiopia," Journal of Infectious Diseases and Therapy, vol. 1, no. 4, 2013.

[11] A. Hailu, K. Negashe, A. Tasew et al., "Sero-prevalence, and associated risk factors of Toxoplasma gondii infection in pregnant women and HIV/AIDS patients in selected cities of Ethiopia," Banat's Journal of Biotechnology, vol. 5, no. 10, pp. 17-29, 2014.

[12] T. Yohanes, S. Debalke, and E. Zemene, "Latent Toxoplasma gondii infection and associated risk factors among HIV-infected individuals at Arba Minch Hospital, South Ethiopia," AIDS Research and Treatment, vol. 2014, pp. 1-6, 2014.

[13] K. Mohammed Yesuf and Z. T. Melese, "Prevalence of toxoplasmosis in HIV/AIDS patients in Mettu Karl hospital," American Journal of Health Research, vol. 3, no. 3, pp. 183-188, 2015.

[14] D. Tegegne, M. Abdurahaman, T. Mosissa, and M. Yohannes, "Anti-toxoplasma antibodies prevalence and associated risk factors among HIV patients," Asian Pacific Journal of Tropical Medicine, vol. 9, no. 5, pp. 460-464, 2016.

[15] J. Negero, M. Yohannes, K. Woldemichael, and D. Tegegne, "Seroprevalence and potential risk factors of T. gondii infection in pregnant women attending antenatal care at Bonga Hospital, Southwestern Ethiopia," International Journal of Infectious Diseases, vol. 57, pp. 44-49, 2017.

[16] A. J. Zeleke and Y. A. Melsew, "Seroprevalence of Toxoplasma gondii and associated risk factors among HIV-infected women within reproductive age group at Mizan Aman General Hospital, Southwest Ethiopia: a cross sectional study," $B M C$ Research Notes, vol. 10, no. 1, Article ID 70, 2017.

[17] E. Ahmadpour, A. Daryani, M. Sharif et al., "Toxoplasmosis in immunocompromised patients in Iran: a systematic review and meta-analysis," The Journal of Infection in Developing Countries, vol. 8, no. 12, pp. 1503-1510, 2014.

[18] E. Z. Gebremedhin and G. Tadesse, "A meta-analysis of the prevalence of Toxoplasma gondii in animals and humans in Ethiopia," Parasites \& Vectors, vol. 8, no. 1, Article ID 291, 2015. 


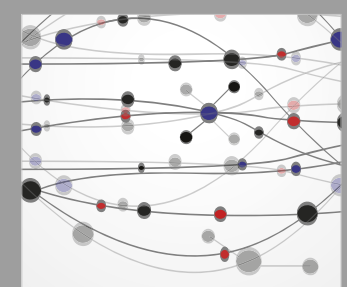

The Scientific World Journal
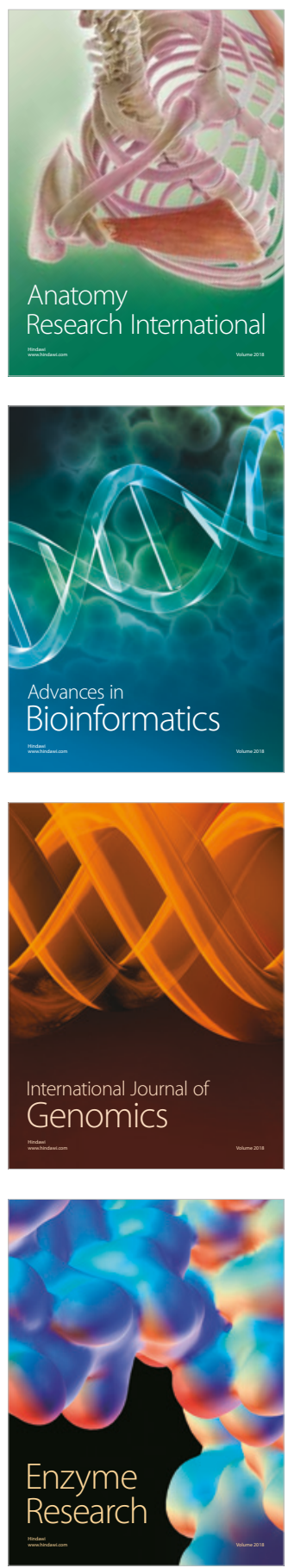
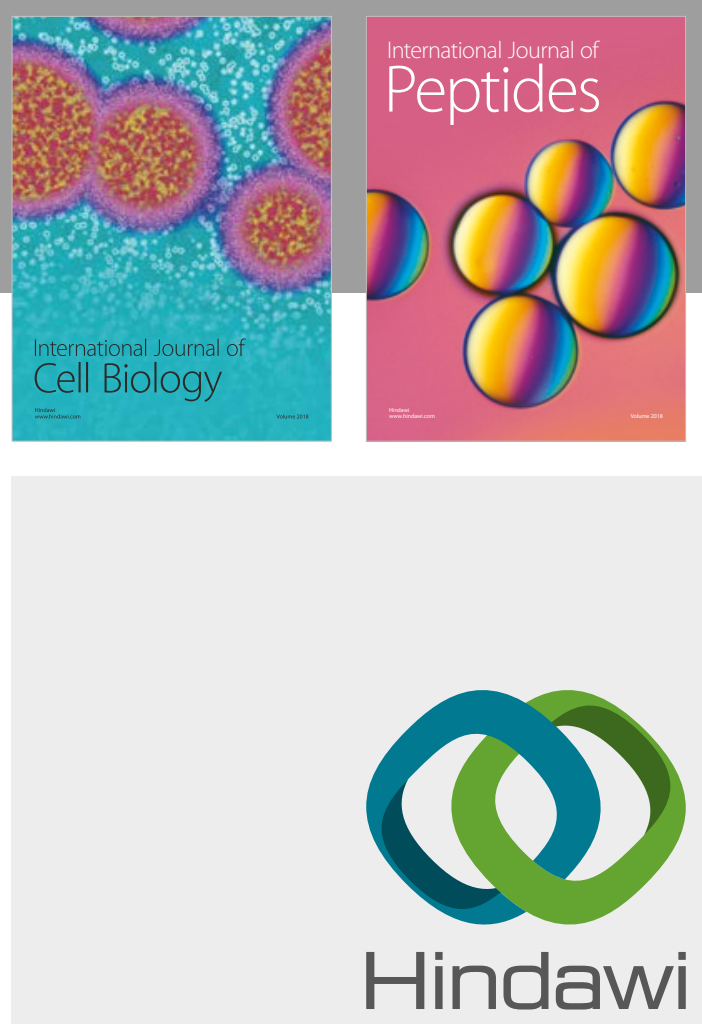

Submit your manuscripts at

www.hindawi.com
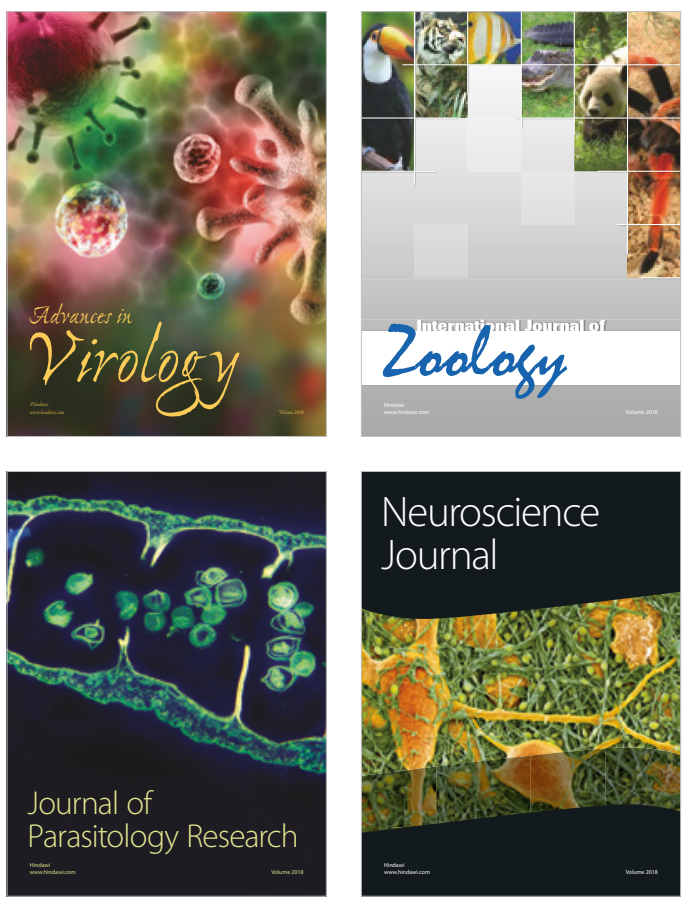
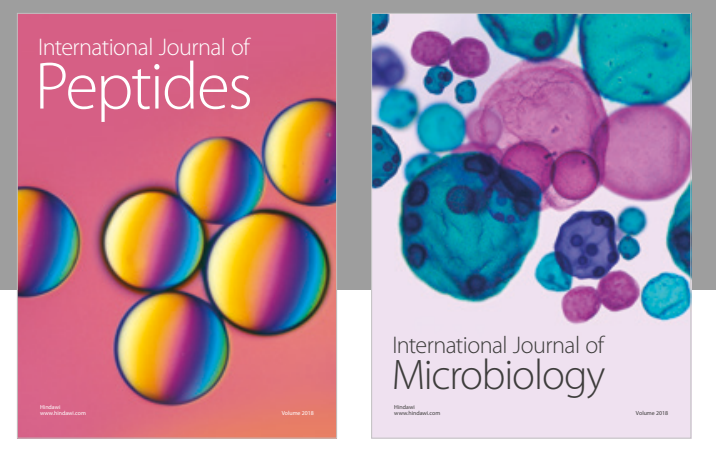

nternational Journal of Microbiology
Journal of
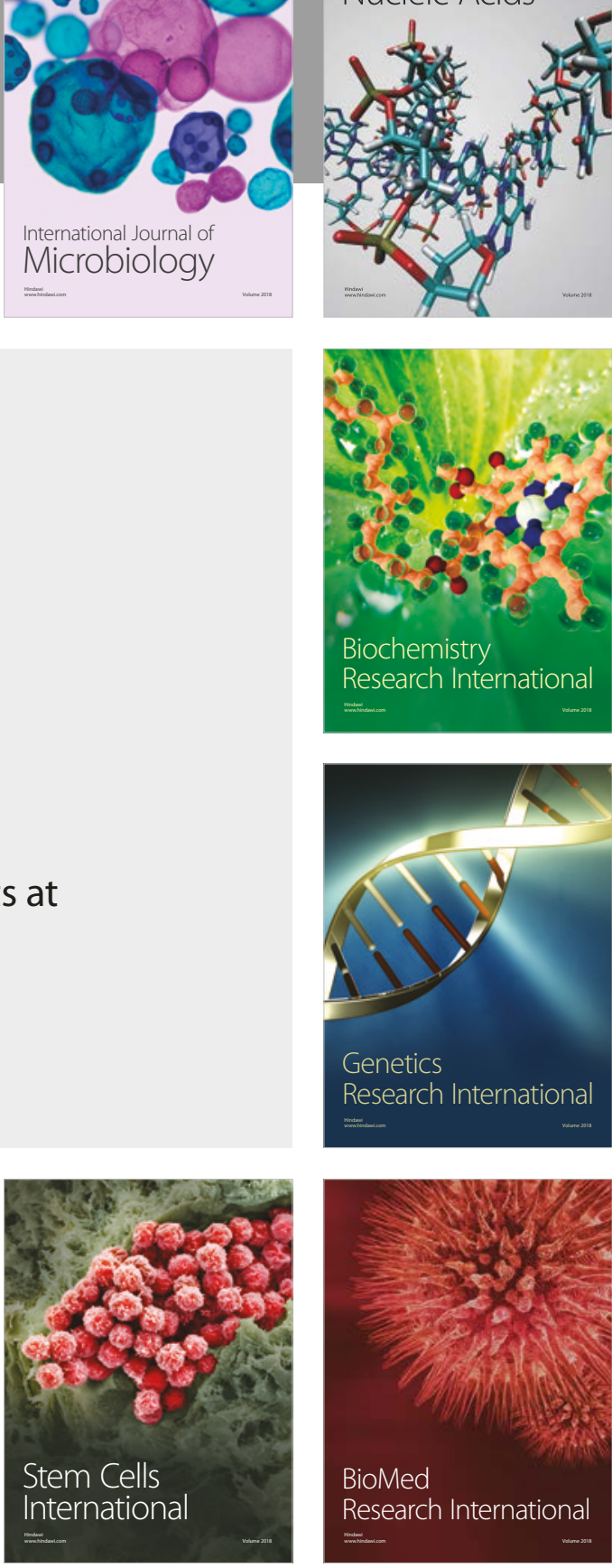
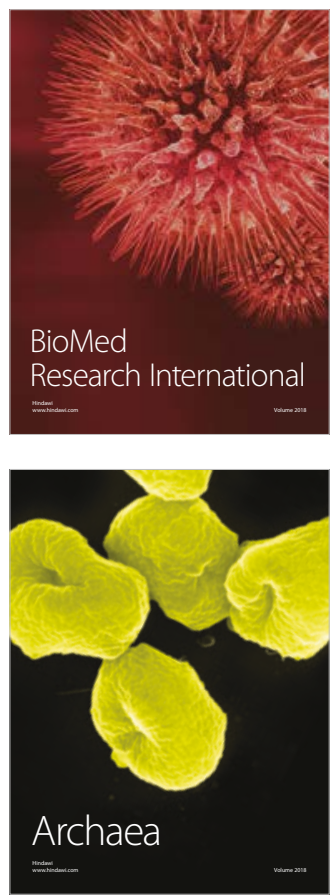